\title{
Studies on the mycorrhiza of Geodorum densiflorum (Lam.) Schltr. from Western Ghats of Karnataka, India.
}

\author{
Jyothsna B.S. ${ }^{1}$ and Purushothama K.B. ${ }^{2}$ \\ ${ }^{I}$ (Department of Botany, Government Science College, Bangalore, India) \\ ${ }^{2}$ (Department of Botany, St. Joseph's College, Bangalore, India)
}

\begin{abstract}
Mycorrhizal association of Geodorum densiflorum (Lam.) Schltr. an endangered terrestrial orchid in the Western Ghats of Karnataka has been investigated. Anatomical studies of the fully grown orchid have revealed the presence of the fungal coils in the cells of the pseudobulb and in the cortical region of the root, indicating the continued association of the fungus with the plant. The degree of colonisation was extensive in the root . Pure culture of the fungus associated with the underground parts of the plant was obtained and identified as Rhizoctonia solani, a common mycorrhiza forming species with many orchids. The rhizosphere soil analysis of the nutrients was carried out which revealed the decreased level of phosphate when compared to nitrogen and potassium. Nutrient analysis supports the fact that mycorrhizal association occurs under the deficiency of soil nutrients like phosphate.
\end{abstract}

Key words : Geodorum densiflorum, orchid mycorrhiza, peloton, Rhizoctonia solani,

\section{Introduction}

Orchid mycorrhiza is the well known symbiotic relationship between orchid roots and a variety of fungi belonging to Fungi Imperfecti like Rhizoctonia and Basidiomycetes like Tulasnella, Sebacina, Ceratobasidium and Thanetophorus [ 1 ].Orchid seeds are very minute, dust like and need symbiotic association of the suitable fungi for their germination, further growth and development into protocorm like bodies (Plbs) as the seeds lack sufficient endosperm. The association continues even in mature plants but the colonisation is restricted mostly to the underground plant parts. The cells of the protocorm and roots are colonized by the fungus which form coiled fungal structure within the cells called pelotons, a distinctive characteristic of orchid mycorrhiza. Pelotons remain stable for varying length of time and were periodically digested by the plant. This interaction between the plant and the fungus is regulated by the plant itself as it releases orchinol, a phytoalexin that causes the pelotons to collapse. The degree of colonization changes over the season, indicating that the orchid is controlling the uptake of nutrients by the fungus preventing parasitism. In terrestrial orchids having annual cycle where a period of growth is followed by loss of leaves and roots, the orchid is maintained below ground generally as tuber, pseudobulb or rhizome until conditions are suitable for growth. The fungus is excluded from the orchid during this period of dormancy but remains in close contact on the underground surface of the plant. As the seedling becomes autotrophic the association then becomes symbiotic.

Geodorum densiflorum is an endangered [ 2 ] ethnobotanically important terrestrial orchid which grows at an altitude of $200-600 \mathrm{~m}$ as an undergrowth in moist deciduous forests. It is widely distributed in India, Nepal, Bhutan, Papua New Guinea, Australia, Bangladesh, Srilanka, China and Himalayas. In India it is distributed in Karnataka, Kerala, Tamilnadu and Maharashtra States. In Karnataka they are found in Kudremukh, Gulbarga, Mysore, Hassan, Uttarakannada and Kodugu[ 3 ]. The pseudobulb is greenish, exposed, persistent and large. Leaves 2-many, uppermost largest, ovate to oblong, elliptic-lanceolate, leaf margin entire, many nerved. Flowers in compact drooping raceme, pinkish white, three lobed spurred and flowers and fruits during MarchJune .It is ethnobotanically important and is locally known by different names like Kukurmuria in Orissa, Donthula gadda in Andhra Pradesh, Shonkhomul in Bangladesh. The root paste is applied for insect bites and wounds, the pseudobulb is used to regularize menstrual cycle[ 4 ], possess anti-diabetic property [ 5 ] and antimicrobial activity[ 6 ]. The present investigation on mycorrhizal status of Geodorum densiflorum is the first attempt from India which may lead to the conservation of this endangered plant in the natural habitats of Western Ghats of India. Physical, physico-chemical and chemical analysis of rhizosphere soil was also attempted to assess the mycorrhizal fungal colonization in the natural habitats.

\section{Materials And Methods}

Geodorum densiflorum was collected from the natural habitats of Western Ghats (Sagar, Shimoga district of Karnataka), India (Fig. 1 a). Methods include: 


\subsection{Isolation of mycorrhizal fungi :}

Standard methods were used for isolation and maintenance of pure cultures [ 7,8 ].Roots and portions of the pseudobulb were used as inoculants. Potato dextrose agar was used for the growth of fungal cultures in petriplates, incubated at room temperature $\left(25^{\circ} \mathrm{C}\right)$.

\subsection{Anatomical studies :}

Thin free hand sections of the root and pseudobulb were taken and stained with tryphan blue $(0.1 \%$ in lactophenol) and observed under the microscope for presence of fungal hyphae in the cortical cells.

\subsection{Analysis of rhizosphere soil samples :}

Standard procedures were followed to determine soil reaction $(\mathrm{pH})$, conductivity (EC), organic carbon, macronutrients $(\mathrm{N}, \mathrm{P}, \mathrm{K})$ and micronutrients $(\mathrm{Fe}, \mathrm{Zn}, \mathrm{Cu}, \mathrm{Mn})$ as outlined by [ 9 ].

\subsection{Fungal isolate :}

\section{Results}

The fungus isolated from the cut ends of root and pseudobulb of Geodorum densiflorum was identified as Rhizoctonia solani (Fig. 1 b).The colony on Potato dextrose agar media was white initially which later turned grayish black with sclerotia. The mycelium was white, submerged, dense; hyphae septate, branched at upright

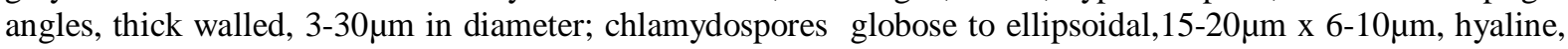
thin walled; sclerotia in clusters, black to brown in colour.(Fig. $1 \mathrm{~h}$ )

\subsection{Anatomical studies :}

Transverse section of the root and pseudobulb showed fungal colonization in the cortical region. The fungus entered the root through the root hairs. Fungal colonization in the form of pelotons was observed as loosely arranged fungal mycelium inside cortical cells of the root and in the superficial cell layers of the pseudobulb. The degree of colonisation of Rhizoctonia solani was extensive in the root cortex from the periphery to inner cortical layers. The same host cells showed both pelotonic and non-pelotonic hyphae. Pelotonic hyphae formed bundles and non-pelotonic hyphae formed a lining layer around the host cell wall, the two being interconnected. Pelotons were many in the root cortex while in the pseudobulb only a few peripheral pelotons were observed.(Fig. $1 \mathrm{~d}, \mathrm{e}, \mathrm{f}, \mathrm{g})$. Digested pelotons were randomly distributed in the cortical cells. Raphides and phenolic substances were present in the cortical cells of both root and pseudobulb.

\subsection{Soil Analysis :}

The rhizosphere soil analysis showed adequate quantity of macro and micronutrients, neutral $\mathrm{pH}$, high organic carbon content. Though the soil was rich with humus, phosphate content was found to be low (Table 1).

\section{Discussion}

Mycorrhizal studies on Geodorum densiflorum is a new report from Indian region. The mycorrhizal fungus isolated was Rhizoctonia solani, an orchid mycorrhiza forming fungus. Mycorrhizal isolation studies on terrestrial orchids of Cycloops[ 10 ] revealed Ceratorhiza and 5 unidentified fungi from Geodorum densiflorum. In the present study, Rhizoctonia solani formed sclerotia in culture and produced chlamydospores. In the anatomical study the degree of colonization of the fungus was extensive in the root than in the pseudobulb which may be due to its sub-aerial conditions. Observation of repeated formation of fungal coils in the same cell indicates proliferation of fungal symbiont within the cortical cells. Similar observation was also reported in Spathoglottis plicata [11]. The pseudobulb showed superficial fungal colonization which serves as a safe site in such seasonally dry soils where the hyphae would have otherwise become shrivelled and dried. Mycorrhizal roots also serve as strong sinks for plant carbohydrates. The hyphal extensions help in absorption, translocation of minerals and water back to the root. Mycorrhizal fungi are efficient in mineral absorption of poorly soluble inorganic nutrients like phosphorus, zinc, copper. Pseudobulb showed many raphides of calcium oxalate in the cells of the cortex preventing herbivory. These crystals have different functions like storage, ionic balance and osmotic regulation. Phenolic substances were seen in the peripheral layers of cortex in the pseudobulb. These substances prevent invasion of fungi in the deeper layers of the cortex, as their function is protecting the plant from invading pathogens and hence pelotons were few in the pseudobulb than in the cortical cells of the root.

The rhizosphere soil from the natural habitat of Geodorum densiflorum was rich in organic carbon and other minerals. However, Phosphorus was scanty in the soil which necessitates forming mycorrhizal association. The reason attributed to the endangered condition of Geodorum densiflorum was due to the loss of top soil which is usually inhabited by the fungus. In vitro germination and micropropagation of Geodorum densiflorum was attempted [ 12 ] excluding the mycorrhizal partner. Pure cultures of the fungal isolate obtained in the 
present study may provide scope for efficient in vitro seed germination and its use in replenishment of the inoculums in natural habitats where Geodorum densiflorum population is less and scarce.

\section{Rhizosphere Soil Analysis}

TABLE: 1

\begin{tabular}{|l|l|l|l|l|l|l|l|l|l|}
\hline & $\mathbf{p H}$ & $\begin{array}{l}\text { EC } \\
\text { (ds) }\end{array}$ & $\begin{array}{l}\text { Organic } \\
\text { Carbon } \\
\mathbf{\%}\end{array}$ & $\begin{array}{l}\text { Phosphoru } \\
\mathbf{s ~ k g / a c}\end{array}$ & $\begin{array}{l}\text { Potash } \\
\mathbf{k g} / \mathbf{a c}\end{array}$ & $\begin{array}{l}\text { Zn } \\
\mathbf{p p} \\
\mathbf{m}\end{array}$ & $\begin{array}{l}\mathbf{F e} \\
\mathbf{p p} \\
\mathbf{m}\end{array}$ & $\begin{array}{l}\mathbf{C u} \\
\mathbf{p p m}\end{array}$ & $\begin{array}{l}\text { Mn } \\
\mathbf{p p m}\end{array}$ \\
\hline Normal limits & $6.3-8.5$ & $\begin{array}{l}\text { Below } \\
1\end{array}$ & $0.5-0.75$ & $9-22$ & $60-120$ & 1 & 2 & 0.2 & 2 \\
\hline $\begin{array}{l}\text { Geodorum } \\
\text { densiflorum }\end{array}$ & 6.9 & 0.13 & $\begin{array}{l}2.02 \\
\text { (High) }\end{array}$ & $\begin{array}{l}8 \\
\text { (Low) }\end{array}$ & $\begin{array}{l}336 \\
\text { (High) }\end{array}$ & $\begin{array}{l}3.97 \\
(\mathrm{~S})\end{array}$ & $\begin{array}{l}15 \\
(\mathrm{~S})\end{array}$ & $\begin{array}{l}1.4 \\
(\mathrm{~S})\end{array}$ & $\begin{array}{l}25.7 \\
(\mathrm{~S})\end{array}$ \\
\hline
\end{tabular}

S- sufficient, ds- decisiemens

\section{FIGURE 1}

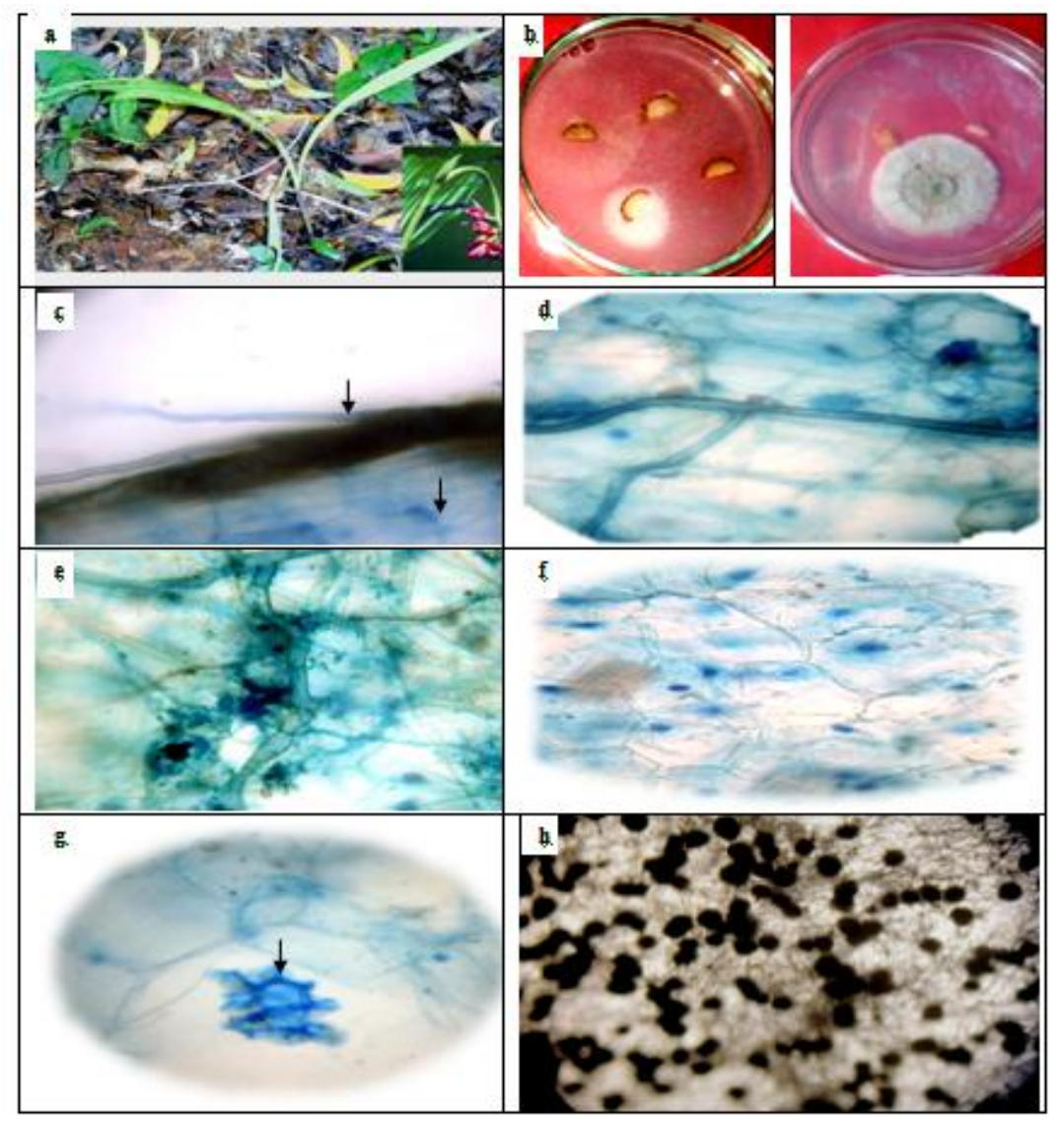

a. Habit-Geodorum densiflorum with inflorescence

b. Isolation of the fungus on PDA from rhizome and the root

c. Light microscopy - T.S. of pseudobulb showing entry of fungal hyphae and pelotons in the peripheral cell (400x)

d. Intracellular fungal hyphae in the cortical cells of the root $(400 \mathrm{x})$

e. Cortical cells showing two kinds of hyphae-thick walled and thin walled hyphae (400x)

f. Cortical cells of the root showing pelotons (400x)

g. Single digested peloton $(400 \mathrm{x})$

h. Sclerotia formation in pure culture $(100 x)$

\section{Conclusion}


The present study on mycorrhizal association of Geodorum densiflorum revealed the prevalence of Rhizoctonia solani in the underground parts of the mature plant. Generally in nature, fruit formation in orchid plants are dependant on the suitable pollinating agents. As the natural habitat of this plant is unabatedly destroyed, there is an urgent need to conserve this medicinally important plant resource. Plant regeneration by micropropagation technique coupled with inoculation of a suitable mycorrhizal fungal partner at the hardening stage would definitely help in the growth and multiplication of the plant under laboratory conditions and further introduction to their natural habitats.

\section{Acknowledgement}

The authors are thankful to the Management of St.Joseph's College, Bangalore for providing the laboratory facilities and to Dr. Divakar, Department of Botany, St. Joseph's College, Bangalore for his help in procuring the plant specimen.

\section{References}

[1]. G. Hadley, Orchid Biology : Reviews and Perspectives (Cornell University Press, Ithaca, New York, 1982) .

[2]. S.S. Sheelavantmath, H.N. Murthy,A.N. Pyati , H.G. Ashok Kumar and B.V. Ravishankar, In vitro propagation of the endangered orchid, Geodorum densiflorum (Lam) Schtr through rhizome section culture. Plant Cell Tissue and Organ Culture 60, 2000, 151154.

[3]. T. Ananda Rao, Conservation of Wild Orchids of Kodagu in the Western Ghats. ( The Karnataka Association for the Advancement of Science, Bangalore, 1998).

[4]. P.K..Dash, S. Sahoo, S. Bal, Ethnobotanical Studies on Orchids of Niyamgiri Hill Ranges Orissa, India. Ethnobotanical leaflets. $12,2008,70-78$.

[5]. J. Roy and N. Banerjee, Rhizome and shoot development during in vitro propagation of Geodorum densiflorum ( Lam.) Schtr. Scientia Horticulturae 94, 2002, 181-192.

[6]. A. Saleha, Z .I. Mohammad and A. Tahira., Antimicrobial activity of different extracts of Geodorum densiflorum (Lam.) Schltr. pseudobulb - Stamford Journal of Pharmaceutical Sciences 3 (2), 2010, 47-48.

[7]. J.L..Harley and S.E. Smith (Ed.), Mycorrhizal Symbiosis ( Academic Press, London, 1983) 268-295.

[8]. P. Davet, F..Rouxel, Detection and Isolation of Soil Fungi. (Science Publishers, Inc. Enfield, NH, USA, Plymouth, UK,2000).

[9]. H.L.S. Tandon (Ed.) Methods of Analysis of Soils, Plants, Water and Fertiliser. (Fertilisers development and consultation organisation, New Delhi, 1993)1- 144.

[10]. A.Verena, S.,Supeni and Suharno,.Mycorrhizal associations of terrestrial orchids of Cycloops Nature Reserve, Jayapura. Biodiversitas 10(4), 2009, 175-180.

[11]. S.Senthilkumar and K..V. Krishnamurthy, A Cytochemical study on the mycorrhiza of Spathoglottis plicata . Biologia Plantarum 41(1), 1998, 111-119.

[12]. S.R. Bhandra and M.M. Hossain M.M. In vitro germination and micropropagation of Geodorum densif;orum (Lam.)Schltr an endangered sp. of Bangladesh., Plant Tissue culture 13(2),2003, 165-171. 